\title{
Role of Innovation in Sustainable Sanitation System: A Case Study of India
}

\section{Rola innowacji w zrównoważonym systemie sanitarnym: studium przypadku Indii}

\author{
Sumit Shekhar*, Amrita Dwivedi ${ }^{\star *}$ \\ Department of Humanistic Studies, IIT (BHU), Varanasi - 221005, India \\ *E-mail: sshekhar.rs.hss18@itbhu.ac.in \\ **E-mail: amrita.hss@itbhu.ac.in
}

\begin{abstract}
Sanitation and water are one of those problems which have been given top priority in the sustainable agenda. However, scanty resources, geographical condition, natural environment, tradition, institutional and financial constraints lead to several challenges of feasibility, affordability, availability, and acceptability. This study reveals the inequality in the access to improved toilet facilities based on wealth index and locality of households using National Family Health Survey (NFHS) data. These problems can be addressed by applying different types of social innovations in which novelty in product and process can play a crucial role. This paper critically examines the role of innovation which can play in expanding transition to sustainable development in the sanitation sector which needs some financial, organizational, and institutional agreement. The progress in sanitation sector is dependent on the consumer behavior. However, it still lacks a variety of quality-price ranges and its utility as the basic needs of dignified life.
\end{abstract}

Key words: sustainable sanitation, innovation, product, process

\section{Streszczenie}

Warunki sanitarne i woda to jedne z najważniejszych wyzwań w kontekście zrównoważonego rozwoju. Zarazem skąpe zasoby, warunki geograficzne, środowisko naturalne, tradycja, ograniczenia instytucjonalne i finansowe prowadzą do kilku wyzwań związanych z wykonalnością, przystępnością cenową, dostępnością i akceptowalnością. Badanie to ujawnia nierówności w dostępie do ulepszonych toalet w oparciu o indeks zamożności i lokalizację gospodarstw domowych na podstawie danych National Family Health Survey (NFHS). Problemy te można rozwiązać, stosując różne rodzaje innowacji społecznych, w których nowość w produkcie i procesie może odgrywać kluczową rolę. $\mathrm{W}$ artykule krytycznie przeanalizowano rolę innowacji, które mogą odegrać istotną rolę $\mathrm{W}$ przejściu do zrównoważonego rozwoju w sektorze sanitarnym, które wymaga finansowego, organizacyjnego i instytucjonalnego zabezpieczenia. Postęp w sektorze sanitarnym zależy też od zachowań konsumentów. Jednak nadal brakuje tu różnych przedziałów jakościowo-cenowych i użyteczności zapewniających podstawowe potrzeby godnego życia.

Slowa kluczowe: zrównoważony system sanitarny, innowacje, produkt, proces

\section{Introduction}

Sustainability is one of the key terms which has been on priority in the Brundtland Report of 1987 to Sustainable Development Goals. This is all about the balance between the wellbeing of present with the consideration of need of the future. The word well being is often used as welfare in the broader sense which demands security, justice, education, freedom, and democracy. The quality of life depends upon the capabilities of human beings to achieve these needs (Sen, 1993). There are a lot of debates on the sustainability over the time. On the contrary, it is not limited only to production, agriculture, ser- 


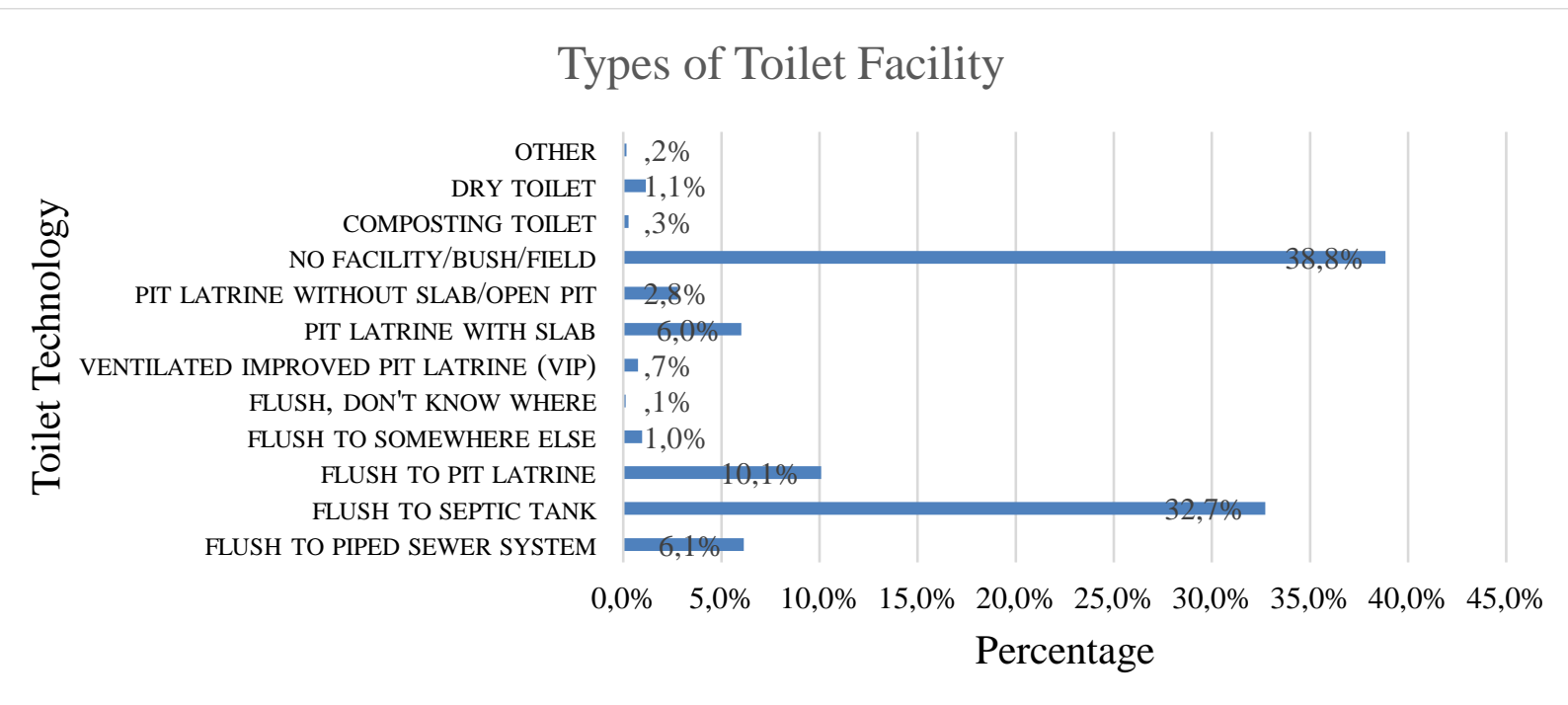

Figure 1. Types of toilet facility used by households in India, source: NFHS 4 (2014-15), compiled by Authors

vices, and manufacturing in the era of cosmopolitism but also concerned with sanitation. Sustainable sanitation is not only required for the basic need of the people in a country but also associated with the economic growth and development of a nation. However, there are multi-level problems in developing countries like India, such as lack of resources and skilled manpower which create a problematic situation. Sanitation has recently got a significant attention in the development agenda and becomes a political priority for the government and non-governmental organizations. Despite relative success in some countries for Millennium Development Goals (MDG) to reduce halves of the proportion of the population without access to sanitation and water, there is still a pathetic situation where a large proportion of the population still practice open defecation and do not have access to improved drinking water source. Till 2015, 2.3 billion population lacked even a basic sanitation service including 892 million population which practice open defecation worldwide. Although $75 \%$ of the population use an improved source of water within the premises (JMP, 2017), yet this situation is more alarming in rural areas as nine out ten, practice open defecation resides in rural areas (UNICEF/WHO, 2015).

Several studies have revealed ill impacts of inadequate sanitation facilities on the socio-economic and environmental status of a nation. Lack of sanitation and water supply have been noted as major causes of spread of various diseases like diarrhea, jaundice, cholera etc. and death of millions of people every year (Dwivedi, 2012). The availability of these facilities also eliminate poverty at the individual level and reduce the expenses on health care facilities of the nation. Apart from this, access to these basic but fundamental amenities reduces the work burden of girls and women and loss of man days. However, it is an alarming fact that India is in the situation of half-empty and half-full status even after the implementation of many programmes and policies.

Making access to these basic facilities to the last person of the community needs a system which is sustainable and affordable. This requires a better understanding of the gaps in the sanitation sector and implementing some innovative model and technology for the solution of the problem. Innovation is at the core of sustainable development. Even, it acquires its place as a goal in a sustainable development goal and as a means to achieve other targets. Social Innovation does not mean only the processes to introduce something new but altering the dynamics of a complex system which can change the flow of resources and information for the betterment of the society. There is a need to understand the broad concept of social innovation to harness the benefits of achieving sustainable sanitation. This paper identifies critical gaps and obstacles in India, which threaten the progress in the sanitation sector and examines the role that social innovation can play in the expanding transition to sustainable development in the sanitation sector.

\section{Challenges in sanitation sector: a complex reality}

Developing countries like India are facing multi-layered challenges, i.e., operational, and structural deficiencies in the sanitation sector. National Family Health Survey (NFHS), 2014-15 factsheet reveals that $48.4 \%$ of the households in India have improved sanitation facilities, whereas $89.9 \%$ of households have improved drinking source of water. However, the state of situation is worse in rural India as only $36.7 \%$ of households has improved sanitation facilities.

Figure 1 reveals that $6.5 \%$ of households in India have flush toilet connected with sewage system. According to one study undertaken by Wankhade 
(2015), two-third of total wastewater generated remains untreated in the urban area alone. The situation is more pathetic in rural and slum areas where sewage infrastructure is in poor state. Besides, 32.84 $\%$ and $10.2 \%$ of household's flush toilet wastewater in pit and septic tank respectively, which can be termed as onsite sanitation system. This type of system requires extensive cleaning process in which cost should be borne by the users. There is no clear plan for emptying of these septic tanks resulting into overflow, contamination, and offensive smell (O'Connell, 2014). Apart from this, pit toilets generally collapse due to poor construction, and some toilets get choked after some use due to improper technology and engineering (Manisha, 2018). This situation forces the community to go again for open defecation. Whereas the transportation of the waste materials for the treatment is quite difficult in informal settlements. There are only six functional fecal treatment plants for 8000 cities in India. This makes it nearly impossible to treat onsite waste generation (Dutta, 2017). According to the Centre for Science and Environment (CSE), there is a generation of 1.75 million tons of excreta in India in which $78 \%$ of excreta are disposed of in open, river and lake (Manisha, 2018). There is evidence of chemical and microbial contamination from pit and septic toilets to the groundwater storage, which affects human health (Shivendra et.al., 2015). This situation leads to epidemics and threaten to quality of both surface water and ground water sources. Hence, this cannot be referred to as sustainable sanitation.

Table 1. Percentage of households who practice open defecation by their wealth category, source: NFHS 4 (201415), compiled by Authors

\begin{tabular}{|l|c|}
\hline $\begin{array}{l}\text { Wealth } \\
\text { Index }\end{array}$ & $\begin{array}{c}\text { Percentage of Population } \\
\text { (open defecation) }\end{array}$ \\
\hline Poorest & 47.0 \\
\hline Poorer & 32.2 \\
\hline Middle & 16.7 \\
\hline Richer & 3.8 \\
\hline Richest & 0.3 \\
\hline
\end{tabular}

Sanitation coverage in India is characterized by the unequal distribution of these basic services. The NFHS data clearly shows that more than $75 \%$ of the households having poorest and poorer wealth index in general practice open defecation. While the situation is quite different in the case of richer section, only $3.8 \%$ households having richer and richest category of wealth index practice open defecation (Table 1). It clearly reveals that, poor specially marginalized group consisting of children and women who were bypassed in the previous programmes and policies are highly exposed to the risk of health hazards due to poor public health system.

The adaptability of toilet technology depends upon several factors like the availability of raw material, skilled labor, purchasing power and behavior of the household. However, the availability of resources mainly depends upon the geographical location. The value of binary logistic regression shows that the richest group tends to use (1/0.005) 200 times of improved sanitation such as offsite sanitation, septic tanks, ventilated improved pit, pit latrine with a slab in comparison to poorest group of community (Table 2). This gap narrows down with the rise in the Wealth Index. It is evident that the wealth of a family highly influences the acceptance of toilet technology. There is also inequality which depends on the locality of the household. Analysis reveals that urban households have more accessibility to the better technology like offsite sanitation, septic tanks, pit latrine with slab, composting toilet, and other technologies in comparison to the rural households. The economic status and regional settlement still influence the selection of toilet technology in India. Hence, the fundamental question arises over here is the capabilities of community to access the welfare scheme by the government (Sen, 1993).

Table 2. Binary Logistic Regression, source: NFHS 4 (2014-15), compiled by Authors

\begin{tabular}{|l|l|c|c|c|}
\hline $\begin{array}{l}\text { Type of toi- } \\
\text { let facility }\end{array}$ & & \multicolumn{1}{|c|}{ B } & Sig. & $\operatorname{Exp}(\mathrm{B})$ \\
\hline \multirow{4}{*}{$\begin{array}{l}\text { Improved } \\
\text { Toilet }\end{array}$} & Intercept & 1.954 & 0.000 & \\
\cline { 2 - 5 } & Poorest & -5.383 & 0.000 & .005 \\
\cline { 2 - 5 } & Poorer & -3.783 & 0.000 & .023 \\
\cline { 2 - 5 } & Middle & -2.715 & 0.000 & .066 \\
\cline { 2 - 5 } & Richer & -1.151 & 0.000 & .221 \\
\cline { 2 - 5 } & Urban & -.156 & 0.000 & .855 \\
\hline
\end{tabular}

There are straightforward available technologies for the treatment of fecal waste, but cultural inclination of Indian people tends to go for flush and forget toilet which is not able to sustain the benefits of sanitation practices. The need of India is quite different from other developed countries in the sanitation sector because of the culture and tradition. It is complex and vivid which is constructed due to various caste, religion, class, language, gender, and region. Toilets in India is taken as impure and ritually polluting. Hence, upper castes in India do not want to clean their toilet by their own which ultimately promotes inequality, untouchability, and manual scavenging (Khare, 1962). Again, open defecation and urination in India are not just accepted by the society but also seen as the symbol of masculinity and strength. Hence, toilets in India is not only about the infrastructural design but also has its roots in the social issue. Moreover, people in India prioritize other expenditure instead of construction of the sanitation infrastructure. This situation arises due to the lack of knowledge about the health-related issues related to sanitation among the community (Bhattacharya et al., 2017).

Studies have revealed that sanitation system in India suffered due to various institutional factors and governance failure (Manisha, 2018). There was little or less debate on toilet technology among the political decision-makers in the past. Again, there has been 
former experience of poor linkages between different agencies involved in the management of sanitation sector like government, municipalities, Panchayats, civil societies, and other external and internal agencies. Within the municipalities, there is no single unit which can be termed as accountable for this sector. In most case, inhabitants did not feel accountable for the availability of public services in the sanitation sector. This may be due to subsidies which have been given by the government in the past (Evans, et al., 2009).

Hence, Sanitation is related to different aspects of community behavior, climate, operation, supply and maintenance of toilet and water resources which need diversified but appropriate infrastructure i.e., optimal use of local resources to develop technology which can address the needs of the people with the consideration of socio-economic condition and cultural practices (Schumacher, 1973).

\section{Social innovation: way to sustainable sanitation}

The WHO/UNICEF Joint Monitoring Program (JMP) defines sanitation as a system in which excreta are managed from the facilities which are used by the individual through emptying and transport of excreta for treatment and eventual discharge or reuse (WHO, 2017). However, sanitation is closely linked to socio-economic, behavior and technological issues. Hence, some definition includes a more inclusive definition of sustainability which ensures the protection of environment and resources, the human health and operation through appropriate technology and institution which is economically viable and socially acceptable (Bracken et al., 2005). Sustainable sanitation is a comprehensive approach rather than a mere technology which ensures fulfilment of a set of criteria to achieve equitable and universal access to services over the long period of time. Sustainability of any services is guaranteed by the community and local government where the community can pay and have skills to utilize it locally and the local government can operate, maintain, extend and replace the infrastructure in order to obtain reliable service (McConville, 2008). Hence, a sanitation system should qualify the criteria of financial viability, social acceptability, simplicity, technicality and institutional appropriateness, and protection and conservation of the environment and natural resources.

It is evident to understand sanitation as system for the successful implementation of the given criteria of sustainable sanitation. These criteria also demand that all the elements in the system are taken together for sustainability and equity in sanitation. The elements of the system are community, nature, infrastructure, and treatment. Community variables are attitude, behavior, economic condition, beliefs and taboo related to the waste and human excreta. Nature includes geographical condition like temperature, humidity, water, and soil. Treatment means the physical, chemical, and biological process for the safe disposal of human excreta and human waste. Infrastructure describes the user interface i.e., type of toilet, latrine or urinal for on-site structure and treatment unit for off-site structure. (Winblad et. al, 2004)

Within Sustainable Development Goal, innovation itself is posited as one of the SDGs (Goal 9) and as a means for achieving other SDG (U. N. ,2016). Innovation should be considered as anything that involves a change which is novel to the individual and community involvement. The term innovation is a broad term containing various components as it incorporates creation, discovery, diffusion, and utilization aspects (Gault, 2016). The questions arise what to create or discover and what to be utilized and by whom? This can directly be taken as the creation of new things which should create technology-based opportunities for a new market and services. Joseph Schumpeter (1934) takes innovation as the novel combination of knowledge resource and products for purpose of commercialization. It is imperative that new products and idea should be diffused among the community for being called innovation.

The role of innovation can be traced out in the development of any nation throughout the history of human civilization. The innovative ideas and products make human life dignified with the imaginative construction of the world. For instance, green innovation makes the city a cleaner and hazards free environment for human. It has also been integrated with a business model which creates a window for the better socio-economic condition through the job creation. It is perceived that innovation can only enhance the large industries. However, innovation can also play a significant role in the terms of social, economic, and environmental benefits under the tree of developmental policies. This type of innovation is often termed as social innovation.

Social innovation is different from other form of innovations because of the focus on the wellbeing and welfare of individual and community. This can be new ideas, products and services which meets the social needs and transform social relationship for social impact ( Murray et al., 2010). However, social innovation is new to the context in which it appears. It might not be entirely new, but it must be new to those involved in its implementation. It is essential to distinguish between the social impact due to innovation and impacts due to social innovation. For instance, the cell phone has a great societal impact but can't be termed as social innovation but the awareness programme through cell phone can be termed as social innovation. One of the most key elements of this type of innovation is people's participation and behavior modification. Thus, social innovation can refer to encompassing products, services, behavior practices, and policies which is novel, satisfy human needs, provide well-being, change social relation, 
Table 3. Different forms of Innovation in the sanitation sector, source: compiled by Authors

\begin{tabular}{|c|c|c|c|c|}
\hline Products & Delivery & Organization & Communication & Policies \\
\hline $\begin{array}{l}\text { Eco-san Model } \\
\text { Garv Toilet } \\
\text { Bio-Toilet } \\
\text { Soil composting sanita- } \\
\text { tion system } \\
\text { Twin Pit Toilet } \\
\text { Precast Textile Rein- } \\
\text { forced Concrete (TRC) } \\
\text { based Toilet }\end{array}$ & $\begin{array}{l}\text { Subsidy } \\
\text { Loan } \\
\text { Micro-credit } \\
\text { Output Based Aid } \\
\text { Sanitary Mart }\end{array}$ & $\begin{array}{l}\text { Monitoring Mechanism } \\
\text { (Using Digital soft- } \\
\text { ware) } \\
\text { Public Private Partner- } \\
\text { ship } \\
\text { Social Enterprise } \\
\text { Changing role of Uni- } \\
\text { versities }\end{array}$ & $\begin{array}{l}\text { Community Lead Total } \\
\text { Sanitation } \\
\text { Awareness Programme } \\
\text { through digital plat- } \\
\text { form } \\
\text { Kalash Yatra to end } \\
\text { Open-Defecation }\end{array}$ & $\begin{array}{l}\begin{array}{l}\text { Strengthening Com- } \\
\text { plaint Redressal Sys- } \\
\text { tems }\end{array} \\
\text { THE PROHIBITION } \\
\text { OF DEFECATION IN } \\
\text { OPEN PLACES BILL, } \\
2019 \\
\text { No Tea And Haircuts } \\
\text { For Those Who Fail To } \\
\text { Use Toilets }\end{array}$ \\
\hline
\end{tabular}

engage beneficiaries and transform social relation for social impact.

In the case of sanitation sector in India, there is a paradigm shift in the recent decades with the launch of different programmes and policies. However, it still lacks at different levels i.e., financial inclusion, behavior modification, institutional arrangements, and appropriate technological choices. Hence, it needs different form of social innovation in products, delivery, communication, organization, and policies (Table 3).

\section{Product Innovation}

The type of sanitation products available in India is limited, which indeed do not fulfil the requirements of the community. There is an urgent need to develop wide range of available technologies which should be affordable, adaptable, simple, and acceptable like low water consumption, sustainable maintenance, and easy operation to solve the sanitation crisis. A sanitation product should prevent pollution with the capability of preventing the direct contact of fecal pathogens to human. Moreover, sanitation technology should be carefully selected with reference to the concerned geographical and socio-cultural condition. For instance, the risk of contamination of groundwater is high due to pit latrines in the areas when groundwater table at less depth and areas prone to flooding. Looking into the problem of poverty rate and cultural practices in India, it is very much necessary that the design should be economically viable and acceptable.

There are different examples where waste materials may act as a potential source of energy and manure. For instance, biogas linked toilet converts waste into a conventional energy source which can be used for various purposes like cooking and electricity. The desired innovation should focus on this component of recycle, renew, and reuse as it creates the opportunity to initiate business and minimize the cost of users. Moreover, the availability of other resources like the availability of skilled workers and techniques for easy installation and maintenance is also required.
There are several products in the sanitation sector which needs to be implemented, commercialized, and utilized promptly with the little improvisation for the sustainable sanitation. For instance, the Vietnamese double vault eco-san toilet which is developed for the people who are the wipers has been implemented for the washers in Kerala by using decomposition process instead of dehydration process (Calvert, 1999).

\section{Process Innovation}

After the development of any product, it should be adopted by the society for being characterized as novel. In the case of sanitation sector in India, there are already some good existing technologies which can serve the need of the nation after a little alteration depending on the local situation. However, the basic problem is the implementation of those technologies which needs some sort of process innovation. Process innovation is the implementation of method for the provision of service and products which is either new or significantly improved from the previous process (Bloch \& Bugge, 2013). In the simple context, it is the new or significantly improved ways of producing or delivering of goods and services. It may be through innovative change in organizational structure or change in the communication strategy. In many cases, there are materials goods that have been improved through technical change which lead growth in the production and delivery. Hence, Process innovation can be further categorized in the delivery innovation, communication innovation, organization, and policy innovation (Gault, 2016).

Delivery innovation is very much vital in the successful implementation of public services as it promotes optimum use of resources and consumer satisfaction. Various agencies like NGO, administration, Companies involved in Corporate Social Responsibility (CSR) are offering the delivery of services in the sanitation sector. However, they are constrained to a particular technology because of government guidelines for the construction of toilets. This hinders the delivery of the sanitation service to the people. Hence, sanitation sector 
needs service level provision approach rather than specifying a particular technological choice. This will give authority to service delivery agency to deliver the product to the community by taking consideration of local socio-economic and cultural condition.

The delivery of the sanitation services is dependent on the accessibility and availability of the products, Skilled labors, and technical capabilities. Rural Sanitation Mart is one of the innovative ways to ensure the accessibility of the products under the various programmes. Self Help Groups (SHG) can also be very useful for the establishment of the production centre of the sanitary product at the local level. A similar example has been seen in the Keeraplayam block of Tamilnadu where informal groups are formed from the revolving fund of the SHG has been used to establish the production center of the toilet pan (Prakash, 2005).

The affordability of the sanitation product is one of the crucial factors in the sustainable sanitation. By taking consideration of the poverty in India, it is imperative to take some innovative way to deliver the sanitation facilities such as subsidy, micro-credit and granting easy loan for the construction of toilet. There is some other innovative way to tackle this problem i.e., Output Based Aid (OBA). Unlike tradition approach, OBA link the payment of the services based on the delivery of sanitation services within the community. In this approach, the delivery is contracted to the third party. However, the Panchayati Raj institution can also act as that third party and get the payment for the delivery.

Communication innovation is like the marketing innovation where organization implement new methods to promote the products and services through significant change in product design, placement, and pricing. However, it is different from marketing innovation at the same time in the context of public services. Firstly, organization involved in the public sector does not have a particular marketplace. Secondly, there is ongoing promotion and campaigning without any delivery of services or product. Hence, communication innovation is the implementation of new methods to influence the behavior of individuals and others (Bloch \& Bugge, 2013). Behavior change is a critical component in the successful implementation of sanitation programme. Tradition approach of behavior change in the sanitation programme includes educational messages focused on germs and diseases associated with poor sanitation. However, this has been acknowledged that these approaches are not very successful for the behavior change (Kelly and Barker, 2016). Hence, it needs more innovative ways of communication depending upon the geographical, economical, and socio-cultural context.

Benefits and beliefs are the determinants of the behavior change in the sanitation practices. One should use these determinants according to the local condi- tion. For instance, Community Lead Total Sanitation approach is successful in Bangladesh because of purdah system due to their religious belief. This is because their toilet can ensure their latent demand connected to their cultural belief. Moreover, there are some other innovative ideas for the behavior change which is developed by the local community. For instance, Kalash Yatra where women of the village go for worship of the deities through those ways where people go for open defecation usually. Social networking sites like Facebook and WhatsApp can be used for the awareness of sanitation. There is a considerable number of subscribers of social networking sites in India. According to an estimate made by STATISTA (2015-23), 422.7 million people will use social networking in India by 2022 . Promotion on this type of platform can give better coverage.

Organizational innovation is about the new method in the organization and management of the work. The workplace and organizational structure are quite important for the improvement in the production and distribution. Innovation requires interaction between different stakeholders, i.e., local suppliers of construction materials, local NGO for imparting skills and technique to the community, Universities that do the research activity and provide technical assistance to train the NGOs. These stakeholders communicate with each other for the better solution of problems. However, there are various loopholes for interaction in this sector. Hence, the mechanism should be developed for the fruitful engagement of all the actors especially community, university and civil society into research and developmental projects.

The involvement of social enterprise in Public Private Partnership can play a crucial role in the drive of sanitation sector. They see social and environmental problems as the business opportunities. Again, these types of organization often have the strong social network and personal funding (Shaw, 2004) . This acts as enablers for the success of sanitation facilities. However, the involvement of private sector in India is limited to maintenance and delivery of sanitation services rather than development of new infrastructural design which is unusual from the business organization. For instance, much of the CSR fund is invested in the construction of the toilet for the community. Hence, it is needed to organize these social enterprises at all levels of sanitation sector.

Sanitation is the subject of state government in India. It means that state government will implement the programmes under the guidance of central government. Government of India has launched various schemes and programmes time to time since independence such as Central rural sanitation programme, Nirmal Bharat Abhiyan, and Swachh Bharat Abhiyan to eliminate open defecation. These schemes involved various institution which is governed by various rules and guidelines. However, these guidelines and rules becomes obstacles in the 
developmental projects. For instance, the implementing authority in the sanitation sector often verifies the infrastructure for the subsidy, which is mentioned in the government manual. This discourages the community to accept the new infrastructural technological development, which can be based on their needs and requirements. This is due to the inadequate knowledge of the actors involved at the different levels of programmes.

There is also poor linkage between different actors in the sector which affects the efficiency of the programmes. Hence, there is need to develop strengthen collaboration between the actors and knowledge at the different level. There should be efficient complaint addressal system in the programmes to ensure the participation of the community. However, there is also needed to put some strong laws and regulation against open defecation at the same time. Recently, Shri Naranbhai Kachhadiya, M.P in lower house has introduced a bill to provide for prohibition of defecation and urinating in open places to keep open places clean and disease free. This can be effective, but these laws and regulation should not be limited to the administration but also from the community decision. For example, Kelwara Gram panchayat in the Merwar region has introduced the rule of no haircut and teas who fails to use toilets. These types of rules and regulation is much more needed from the community decisions.

\section{Barriers in innovation: an Indian sanitation sce- nario}

India has attained its status of being one of the largest growing economies of the world in recent years and continues to mark its position among developing countries for its scientific research. It ranked $48^{\text {th }}$ in the list of Global Innovation Index in 2020 which is the best performance of India till now (WIPO, 2019). However, this figure only shows the overall performance of research and development in several sectors in India. The situation of research and development remains pathetic in the sanitation sector. The innovation in sanitation sector can be classified as pro-poor innovation because of the nature of the need of the marginalized community. It has been observed that several households with less income generally practice open defecation.

There are various problems in innovation in sanitation sector on account of financial, institutional, and organizational obstacles. The recent paradigm of Indian Innovation system shows that the role of technology in attaining developmental challenges has been found least efficient for the marginalized community. Private industries and corporate sectors are not able to trace the need for the poor because of their profit-making attitude (Dhar, et al. 2014). Hence, it requires investment from the government.

Fig. 2 shows that there is only 1628 publication till 2020 in while majority of research is done after
2000. The most number of the publication i.e., 157 has been done in 2019 just after completing five years of Swachh Bharat Abhiyan. Again, there are six medical colleges or universities in the list of top ten affiliation for the publication in Scopus indexed journals. So, it is evident that the involvement of the educational institution and research institute is much less than medical colleges and university in the term of publication of Scopus indexed journals. Hence, the volume of publication should be increased, majorly by the research institution and NGOs for the knowledge creation in the sanitation sector.

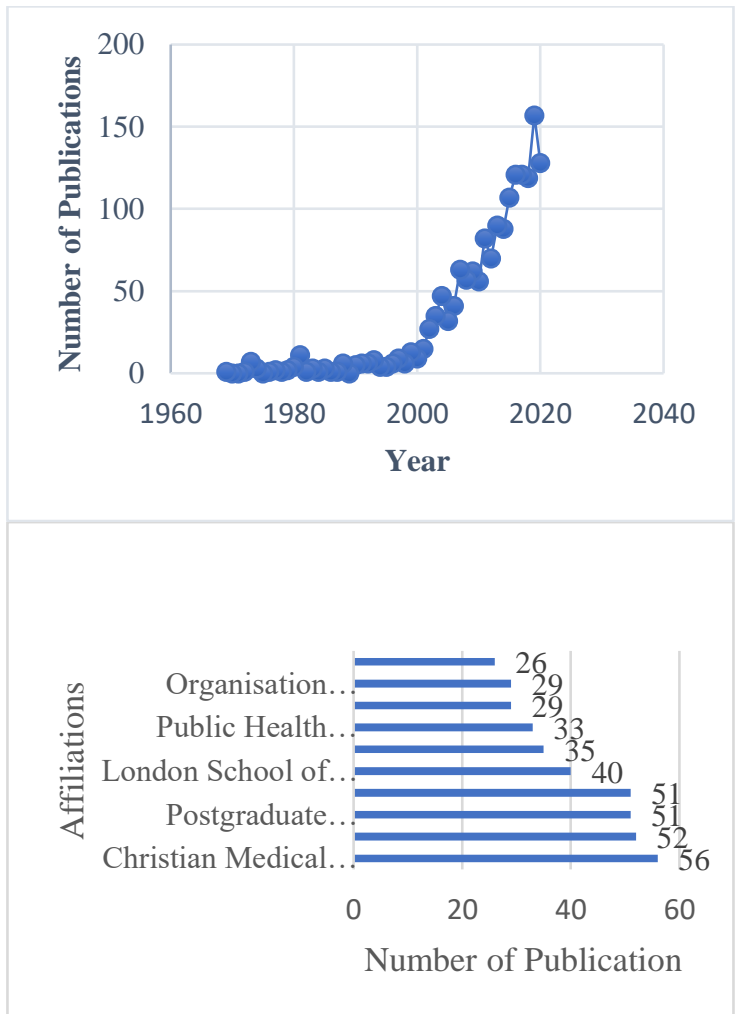

Figure 2. Publication pattern in the area of sanitation In India during the period 1969-2020, source: SCOPUS Data base

The number of research and development projects sanctioned is six in 2017-18 and thirteen in 2018-19 under the Swachh Bharat Mission-Gramin (SBM-G) and water sector respectively. The country like India requires huge investment in the $R \& D$ in the sanitation sector where geographical, social and economic conditions are very diversified Moreover, innovation requires interaction between different stakeholders, i.e., local suppliers of construction materials, local NGO for imparting skills and technique to the community, and universities that do the research activity and provide technical assistance to train the NGOs. These stakeholders communicate with each other for the better solution of problems. However, there are various loopholes for interaction in this sector. There may be a difference of opinion among NGO and universities regarding standardization in the sanitation 
sector. This makes difficult to understand the need for end-user.

Institutions should broaden their roles in the innovation system. The role of education institution seems to limit at imparting skills by providing education and for research and development activities. However, much more can be contributed by these educational institutions (Etzkowitz, 2008). For instance, the responsibility is given by the central government of India to different IITs for making some villages open defecation free under the Namami Gange Project. This initiative will make scholars understand more about the community. The difference of view between practitioner and innovator may be easily eliminated. There is only one rural technology park which is focused on sustainable rural housing technologies under the National Institute of Rural Development and Panchayati Raj. This type of more scientific park is needed all over India.

\section{Conclusion}

There are numerous problems in development of the sanitation sector, such as poor infrastructure, inequality, financial constraints, social unacceptance due to norms and institutional constraints. The approach towards sustainable sanitation can provide various opportunities of social, financial and environmental benefits in the long run. A sanitation system should qualify the criteria of economic viability, social acceptability, technicality and institutional appropriateness, and protection of the environment and natural resources. However, the problems regarding technological choices, poverty, awareness, and education still hampers the adoption by community. These problems need to be addressed through inputs which requires some financial, organizational, and institutional agreement. There is need of better infrastructure, suitable institutional framework, and community participation to achieve the goal for sanitation for all.

Here, the innovation in products and process plays a crucial role by providing better infrastructure and implementation process keeping in view the concern of geographical condition, resource availability, socio-economic need, and cultural belief. There are various constraints in the path of developing innovation for the sanitation sector. Less or no involvement of the private sector, entrepreneur, and research institute act as barriers in the innovation system. However, India can manage the constraint in the innovation of the sanitation sector with the improvement in the organizational and institutional framework.

\section{References}

1. BHATTACHARYA M., JOON V., JAISWAL V., 2011, Water handling and sanitation practices in rural community of Madhya Pradesh: A knowledge, attitude and practice study, Indian $J$ Prev Soc Med, 42(1): 94-97.
2. BLOCH C., BUGGE M. M., 2013, Public sector innovation - From theory to measurement, Structural change and economic dynamics, 27: 133-145.

3. BRACKEN P., KVARNSTRÖM E., YSUNZA A., KÄRRMAN E., FINNSON A., SAYWELL D., 2005, Making sustainable choices-the development and use of sustainability oriented criteria in sanitary decision making, Proceedings of the 3rd International Ecological Sanitation Conference, Durban, South Africa: 486-494.

4. CALVERT P., 1999, Low Cost Sanitation in Water Logged and High Water Table Areas, Proceedings of the National Seminar on Rural Sanitation, Rajiv Gandhi National Drinking Water Mission and UNICEF 1998: 146-151.

5. DHAR B., SAHA S., 2014., An Assessment of India's Innovation Policies, Research and Information System for Developing Countries.

6. DUTTA S., 2017, September 12, Leh Gets One Of The First Faecal Sludge Treatment Plants In The World At An Altitude Of 11,400 Feet Features, ed. Bhaskar, S., https://swachhindia.ndtv.com/leh-getsone-of-the-first-faecal-sludge-treatment-plants-inthe-world-at-an-altitude-of-11400-feet-11737/ (01.07.2020).

7. DWIVEDI A., 2012, Sanitation and human health in developing countries, LAP Lambert Publishing.

8. ETZKOWITZ H., 2008, The triple helix: universityindustry-government innovation in action, Routledge.

9. EVANS B., VAN DER VOORDEN C., PEAL A., 2009, Public funding for sanitation-the many faces of sanitation subsidies, Water Supply \& Sanitation Collaborative Council.

10. GAULT F., 2016, September, Defining and measuring innovation in all sectors of the economy: policy relevance, Proceedings of the OECD Blue Sky Forum III, Ghent, Belgium: 19-21.

11. India: Number of social network users 2022 Statistic, 2020, https://www.statista.com/statistics/278407/nu number-of-social-network-users-in-india/ (01.07.2020).

12. INTERNATIONAL INSTITUTE FOR POPULATION SCIENCES (IIPS), 2017, National Family Health Survey 2015-16 (NFHS-4): national factsheet, IIPS, Mumbai, India.

13. KELLY M. P., BARKER M., 2016, Why is changing health-related behaviour so difficult? Public health, 136: 109-116.

14. KHARE R. S., 1962, Ritual purity and pollution in relation to domestic sanitation, The Eastern Anthropologist, 15(2): 125-139.

15. MANISHA M., 2018, SDG-6 in India: Challenges and Innovation for Sustainable Sanitation, Working Paper No. 2018-05.

16. MCCONVILLE J. R., 2008, Assessing sustainable approaches to sanitation planning and implementation in West Africa, Doctoral dissertation, KTH.

17. MURRAY R., CAULIER-GRICE J., MULGAN G., 2010, The open book of social innovation, National endowment for science, technology and the art, London.

18. O'CONNELL K., 2014, What influences open defecation and latrine ownership in rural households?: findings from a global review, World Bank Group: Water and Sanitation Program, The World Bank, Washington. 
19. PRAKASH M., 2006, Ensuring Water and Sanitation: The SHG Way. SANITATION FOR ALL STILL A LONG WAY TO GO, 12., WaterAid India: 66-74

20. SCHUMACHER E. F., 1973, Small is beautiful: a study of economics as if people mattered, Vintage.

21. SCHUMPETER J. A., (1912)., 1934, The theory of economic development.

22. SEN A., 1993, Capability and well-being, In: The quality of life, ed. Nussbaum, M. Sen, A., Clarendon Press, Oxford: 30-50.

23. SHAW E., 2004, Marketing in the social enterprise context: is it entrepreneurial? Qualitative Market Research: An International Journal, 7: 194-205.

24. SHIVENDRA B. T., RAMARAJU H. K., 2015, Impact of onsite sanitation system on groundwater in different geological settings of peri urban areas, Aquatic Procedia, 4: 1162-1172.

25. UNITED NATIONS., 2016, Sustainable development goals report 2016, UN.
26. WANKHADE K., 2015, Urban sanitation in India: key shifts in the national policy frame, Environment and Urbanization, 27(2): 555-572.

27. WHO., UNICEF., 2017. Progress on drinking water, sanitation and hygiene: 2017 update and SDG baselines, Joint Monitoring Programme.

28. WINBLAD U., SIMPSON-HÉBERT M., CALVERT P., MORGAN P., ROSEMARIN A., SAWYER R., XIAO J., RIDDERSTOLPE P., ESREY S.A., GOUGH J. AND RAPAPORT D., 2004, Ecological sanitation, Stockholm Environment Institute, Sweden.

29. WORLD INTELLECTUAL PROPERTY ORGANIZATION (WIPO), 2019, The Geography of Innovation: Local Hotspots, Global Networks, WIPO.

30. WORLD HEALTH ORGANIZATION, WHO/ UNICEF JOINT WATER SUPPLY, SANITATION MONITORING PROGRAMME, 2015, Progress on sanitation and drinking water: 2015 update and MDG assessment, World Health Organization. 